\title{
Teacher-student Interaction in Novel and Poetry Classrooms in the Hong Kong Tertiary Setting
}

\author{
Dan Shi \\ Division of English Language Education, Faculty of Education, The University of Hong Kong, Hong Kong SAR, China
}

\begin{abstract}
This paper was designed to investigate the linguistic characteristics of the teacher-student interaction in novel and poetry classrooms in the Hong Kong tertiary setting by means of the Sinclair and Coulthard Model (1975), with audio data collected via non-participant classroom observation in two Hong Kong tertiary institutions. Underpinned by the characteristics derived and a comparison undertaken, it can be seen that teacher-student interaction in the free teaching exchange of teacher elicit is in conformity with the exchange structure of IRF in both literature classrooms, to which other free and bound exchanges are complementary. However, the application of the acts varies considerably, implying that distinct learning outcomes are yielded by the different literary genres, with the cultivation of critical thinking emphasized in the novel classroom, and the understanding of technical terms and the enlargement of vocabulary stressed in the poetry classroom.
\end{abstract}

Index Terms — classroom interaction, literature education, spoken discourse analysis

\section{INTRODUCTION}

With a combination of both linguistics and education, classroom research has been laid strong emphasis on for the reason that "the process of learning and teaching is realized through language to a significant extent, and can be studied" (Sinclair, 1987, p.1). With the value of classroom research having been recognized, it has undergone a sustainable development which can be traced back to the late 1940's when there was "a growing interest in studies of language interaction inside the classroom" (Sinclair \& Coulthard, 1975, p.15), while modern classroom research came into being in the 1950s, during which teachers became engaged in investigating the constitution of effective teaching in the classroom (Allwright \& Bailey, 1991, p.6). In the early 1970s, classroom discourse started to gain tremendous attention (Van Dijk, 1985). Teacher-student interaction, as opposed to the teacher-centered instruction, has been attached great importance to in language classrooms (Chaudron, 1988; Allwright \& Bailey, 1991; Wu, 1993; Bailey \& Nunan, 1996; Walsh, 2002), in content classrooms (Chaudron, 1983; Schinke-Llano, 1983, Tsui, 2004), and in content and language integrated learning classrooms (Dalton-Puffer, 2007).

However, classroom interaction in literature teaching can be difficult in L2 tertiary context in the sense that teacher-centered mode of instruction has taken its dominant position mainly due to the disparity of power and knowledge between teachers and students (Parkinson \& Thomas, 2000). This impediment aroused my interest in conducting research into the teacher-student interaction in the literature classroom instructed by professional English literature teachers to track down how literature is taught by English native speakers. Through preliminary classroom observation, it has been found out that discourse in the literature classroom cannot be generalized affected by distinct interactive structures within different literary genres. Hence, the research focuses on the description of how different literary genres can affect the spoken discourse of teacher-student interaction which is premised on the assumption that discourse in the literature classroom cannot be generalized. It would be reflected by an insight into the teacher-student interaction in the literature classroom with the interactive structure as well as the interactive distinction in both novel and poetry classrooms being revealed, which could enable literature teachers to obtain an in-depth comprehension of the teacher-student interaction in the literature classrooms, and at the meantime provide a solid theoretical reference for their literature teaching.

Based on the analysis of teacher-student interaction in literature classrooms, distinct learning outcomes yielded by different literary genres can be unfolded. Accordingly, this paper aims to identify the linguistic characteristics of teacher-student interaction in novel and poetry classrooms in the Hong Kong tertiary setting with the application of the Sinclair-Coulthard Model (1975), with the second section centering on undertaking a comparison of spoken discourse in novel and poetry classrooms with regard to exchange structure, teaching exchanges and acts used by virtue of the features explored. Qualitative approach has been conducted by means of classroom observation in two Hong Kong tertiary institutions with a view to obtaining an in-depth comprehension of the nature of the classroom interaction in these literature classrooms, as well as to stimulating appropriate application of different literary genres to promote cultural enrichment as well as language proficiency through literature teaching.

\section{Sinclair \& COUlThard MOdel (1975) REVISITED}

The model adopted in this paper can be referred to as the Sinclair-Coulthard Model (1975) which aims to "examine 
the linguistic aspects of teacher and student interaction" (Sinclair \& Coulthard, 1975, p.1). This descriptive model is composed of five hierarchical ingredients with an application of a "rank scale", in which the structure of each rank above the lowest can be represented by the rank below (Sinclair \& Coulthard, 1975, p.20). The term of the five ranks first coined by Sinclair and Coulthard (1975), i.e. "act", "move", "exchange", "transaction", and "lesson", have been widely employed in the analysis of linguistic features of the spoken discourse in the classroom (p.24).

Most classroom research carried out with the application of the Sinclair and Coulthard Model (1975) has been mainly underpinned by the third rank, in which the structure of the free exchange I R F has been attached great importance.

Hellermann (2003) laid emphasis on the third turn of the I R F exchange to examine "the interactive import of prosody from a perspective of participants' orientation to talk in interaction" (p.79), and the data were obtained from two different secondary classrooms in US Midwest (p.84), while another research article composed by Basturkmen (2000) was designed to investigate "the sequential patterns of talk in discussion" in UK university classes applying the exchange structure (p.249). Moreover, in the same year, Nassaji and Wells (2000) elucidated the diverse forms and functions of the I R F structure in the teacher-student interaction as well as the influence that the follow-up move has exerted on the students' participation (p.382). It can be seen that all the model-based classroom research types, to a certain extent, focus on the third rank of exchange elaborated by Sinclair and Coulthard (1975) in the native institutional setting.

Classroom research based on I R F exchange has also been undertaken in non-native second language learning classrooms. The two main roles that the follow-up move in I R F exchange plays in EFL or ESL classroom discourse have been elaborated (Cullen, 2002, p.117). The third turn in I R F exchange has been explicated by Lee (2007) as well from the perspective of "local contingency" with data attained from ESL classroom interactions (p.1204). It can be pointed out that the third turn, i.e. the follow-up move, in the I R F exchange has exerted a strong influence on second language learning. By contrast, this paper aims to identify the characteristics of teacher-student interaction based on three ranks, i.e. acts, moves, and exchanges.

\section{NON-PARTICIPANT ClASSROOM OBSERVATION BASED DisCOURSE ANALYSIS}

In Hong Kong tertiary education, English is the major medium of instruction. For English majors studying in Hong Kong tertiary institutions, English is not only considered as a second language in which language skills need to be well mastered, but also as a study tool, by virtue of which knowledge regarding English culture and humanities can be better grasped. It is on account of this aspect that English majors are distinct from non-English majors who consider English only as a communicative tool. Though non-English majors are capable of speaking English, yet they lack a systematic education in other content knowledge associated with the language of English. Therefore, the subjects of this research are within the range of English majors in Hong Kong tertiary institutions.

Permissions were obtained from two literature teachers to both audit and audio record the classes for the research purpose. Both of them are both native speakers of English and have accumulated a wealth of teaching experience in novel and poetry in Hong Kong tertiary institutions. The detailed background information is shown in Table 1 . In this study, an audio recording was made in the course of non-participant observation in two literature classrooms at two universities in Hong Kong. When undertaking non-participant observation, notes were taken as well in terms of the content of the lessons and the interaction between teacher and students to aid the transcription. Having been audio recorded, the teacher and student interaction in the target literature classrooms was transcribed and analyzed using the Sinclair and Coulthard Model (1975), where the nature of teacher-student interaction has been unveiled facilitated by the perception of interactive features for pedagogical implications.

TABLE 1

AN OUTLINE OF THE LITERATURE CLASSROOMS OBSERVED

\begin{tabular}{lllll}
\hline Tertiary Institutions & Teachers (Native speaker) & Subjects & Classes (Sizes) & Grade \\
\hline University 1 & Teacher 1 & Novel & 15 & Second-year undergraduates \\
University 2 & Teacher 2 & Poetry & 24 & Second-year undergraduates \\
\hline
\end{tabular}

\section{FINDINGS AND DisCUSSION}

A. Teacher-student Interaction in the Novel Classroom 
TABLE 2

TEACHER-STUDENT INTERACTION IN THE NOVEL CLASSROOM

\begin{tabular}{|c|c|c|c|}
\hline $\begin{array}{l}\text { Teaching } \\
\text { Exchange }\end{array}$ & $\begin{array}{l}\text { Opening (I) } \\
\text { Act, Move Structure }\end{array}$ & $\begin{array}{l}\text { Answering (R) } \\
\text { Act, Move Structure }\end{array}$ & $\begin{array}{l}\text { Follow } \\
\text {-up (F) Act, MS }\end{array}$ \\
\hline $\begin{array}{l}\text { Teacher } \\
\text { Elicit }\end{array}$ & $\begin{array}{l}\text { Now, } \\
\text { (marker, signal) } \\
\text { The way we are going } \\
\text { to do this is each going } \\
\text { to pick a passage and } \\
\text { talk about them... } \\
\text { (elicitation, head) }\end{array}$ & $\begin{array}{l}\text { It's on page } 85 \text {, about the middle of the page. This quote is quite } \\
\text { interesting, as it explores the relation between lie and truth. Truth in this } \\
\text { novel, I think, is a lie. Because, um, even Paul Auster in this novel is } \\
\text { fictional. In reality, he does not really have a conversation with Quinn, } \\
\text { and also by the, by the first or third meeting between Stillmam and also } \\
\text { Quinn. He speaks his real name. He discloses it, but um we can not say } \\
\text { that it is really true, and it is also interesting um when he said, when } \\
\text { Stillman says that, um... so, I am wondering, m, what does living mean } \\
\text { exactly? (reply, head) }\end{array}$ & $\begin{array}{l}\text { Wow } \\
\text { what does life } \\
\text { mean? } \\
\text { (accept, } \\
\text { pre-head) }\end{array}$ \\
\hline
\end{tabular}

The Table 2 shows a typical spoken discourse concerned with the teacher-student interaction taking place in the novel classroom. The act of marker serving as signal was applied to signify that the teacher's previous lecture on post-modernism has come to a halt and another phase of students' discussion of the novel was scheduled to commence in this lesson, where students were required to pick a passage from the designated novel and talk about it. Without being nominated, one of the students took the initiative in providing a reply with a lengthy statement. Having made clear the location of the chosen passage, the student set out her own point of view in detail and ended her statement with a rather abstract and profound question of what life means. The reply of the student was likely to represent her inner feeling towards what has been portrayed in the novel and combine it with her own experience as well, leading to the generation of a final rhetorical question. Having heard and understood the reply made by the student, the teacher accepted it by the repetition of the last question without any evaluation having being given in view of no common ground existing for the explanation of the meaning of life.

From the analysis above, it can be derived that the structure of I R F in teacher elicit has been basically conformed to in this interaction between teacher and students. However, unique features have come into being as well in this example. Plenty of space was provided by the teacher in posing questions, with the reply characterized by a long statement given by the student followed by the feedback realized via the act of accept. However, evaluation was not expressed by the teacher on the grounds that the understanding of literary texts varies considerably among readers according to their personal experience and knowledge. Therefore, the unfixed answer elicited by the open questions posed in the novel classroom normally cannot be evaluated by the right or wrong dichotomy.

TABLE 3

TEACHER-STUDENT INTERACTION IN THE NOVEL CLASSROOM

\begin{tabular}{|c|c|c|c|c|c|}
\hline $\begin{array}{l}\text { Teaching } \\
\text { Exchange }\end{array}$ & $\begin{array}{l}\text { Opening (I) Act, Move } \\
\text { Structure }\end{array}$ & \multicolumn{3}{|l|}{$\begin{array}{l}\text { Answering (R) } \\
\text { Act, Move Structure }\end{array}$} & $\begin{array}{l}\text { Follow-up (F) } \\
\text { Act, MS }\end{array}$ \\
\hline $\begin{array}{l}\text { Teacher } \\
\text { Elicit }\end{array}$ & $\begin{array}{l}\text { Are fictions always lies? } \\
\text { (elicitation, head) }\end{array}$ & \multicolumn{4}{|c|}{$\begin{array}{l}\text { P1: No, (reply, head) } \\
\text { this point should depend on the reality, believe ourselves. Through } \\
\text { some lies, the author rebuild something true or something } \\
\text { necessarily or ultimately real, like the fictional, like the fictional } \\
\text { natural of all our ...because the author is quite conscious of all this } \\
\text { fictions. (comment, post-head) }\end{array}$} \\
\hline $\begin{array}{l}\text { Bound } \\
\text { exchange } \\
\text { (Listing) }\end{array}$ & $\begin{array}{l}\text { Anybody else? } \\
\text { (nomination, } \\
\text { select) } \\
\text { Truth? Lies? } \\
\text { (clue, post-head) }\end{array}$ & \multicolumn{3}{|c|}{$\begin{array}{l}\text { P2: Maybe, maybe the author is playing with some...our } \\
\text { expectation that sometimes I mean fictions are made to lies. } \\
\text { Because it is fiction, it has to make stories, but we as readers, enjoy } \\
\text { the lies, the stories, the fictional construction. So but in this story } \\
\text { here, the lie are not entertaining at all, boring...(reply, head) }\end{array}$} & $\begin{array}{l}\text { I'm not sure } \\
\text { whether it is } \\
\text { entertaining. } \\
\text { (evaluate, } \\
\text { head) }\end{array}$ \\
\hline $\begin{array}{l}\text { Teaching } \\
\text { Exchange }\end{array}$ & $\begin{array}{l}\text { Opening (I) } \\
\text { Act, Move Structure }\end{array}$ & & \multicolumn{2}{|l|}{$\begin{array}{l}\text { Answering } \\
\text { (R) Act, MS }\end{array}$} & $\begin{array}{l}\text { Follow-up (F) } \\
\text { Act, MS }\end{array}$ \\
\hline $\begin{array}{l}\text { Teacher } \\
\text { Inform }\end{array}$ & \multicolumn{4}{|c|}{$\begin{array}{l}\text { I just think that what, you know, the fiction is a lie, right? On what } \\
\text { level? Um, we said that the fiction is a lie, so we are in the fiction. } \\
\text { It seems to possess truth. We accept that as a truth because it is in } \\
\text { the context...maybe we are in the fiction, you've got lies as well, } \\
\text { but almost end up with double negatives, so the lie will be in the } \\
\text { lie actually becomes a truth...(informative, head) }\end{array}$} & $\begin{array}{l}\text { That's right. } \\
\text { A lie paradox... } \\
\text { (evaluate, head) }\end{array}$ \\
\hline $\begin{array}{l}\text { Teaching } \\
\text { Exchange }\end{array}$ & \multicolumn{3}{|l|}{$\begin{array}{l}\text { Opening (I) } \\
\text { Act, Move Structure }\end{array}$} & \multicolumn{2}{|c|}{$\begin{array}{l}\text { Follow-up (F) } \\
\text { Act, Move structure }\end{array}$} \\
\hline $\begin{array}{l}\text { Student } \\
\text { Inform }\end{array}$ & \multicolumn{3}{|c|}{$\begin{array}{l}\text { There is a hierarchy there. It is the phenomenal world and also the fictional world } \\
\text { and he plays with his boundaries without introducing the boundary into language. } \\
\text { Because in natural language, natural language is semantically closed. We can } \\
\text { indicate this is fiction, this is our real world. But in fiction, but in, year, but in fiction } \\
\text { or in logic, everything is mixed together and one way of dealing with in formal logic } \\
\text { is to introduce some hierarchy like true one or true two. (informative, head) }\end{array}$} & \multicolumn{2}{|c|}{$\begin{array}{l}\text { Yeah (accept, pre-head) } \\
\text { That is a very neat solution. } \\
\text { (evaluate, } \text { head) } \\
\text { In the way, we have to impose } \\
\text { those hierarchies in order to } \\
\text { enjoy fiction. } \\
\text { (comment, post-head) }\end{array}$} \\
\hline
\end{tabular}

The second discourse begins with the teacher's elicitation about whether fictions are always lies, in which a yes-or-no question has been posed (See Table 3). Without nomination, equal chances of answering the question were granted to all 
students in the classroom, who were eligible to express their viewpoints without any restriction. In the answering move, apart from the reply of a "no" being provided by one of the students, the comment with a long statement pertaining to how the reply "no" was drawn was contributed in order to provide additional information as well as to support her viewpoint. However, feedback was not given by the teacher immediately, with an intention to gain a more comprehensive view of student's understanding from enquiring more students before contributing his own opinion. Having obtained two students' responses, each of which was expressed with a long statement, the teacher provided his feedback in hedging for the students engaged in the interaction. Since no definite answer can be drawn from the open questions posed in this novel classroom, neither right nor wrong can be used to measure the responses suggested by the students. Any explanation was acceptable as long as it was reasonable and relevant.

To further expound on his own understanding, the teacher started lecturing in the third teaching exchange of teacher inform. Instead of the head of acknowledge employed corresponding to that of informative, the act of comment functioning as post-head was used not only to show the student's understanding but also to generalize from what had been instructed. In accordance with the teacher's sharing on the relationship between fictions and lies, one of the students was capable of summarizing what the teacher has just stated into a concise noun phrase, being equivalent to the long statement delivered by the teacher. In the phase of tertiary education, students have gradually developed the capability of inductive reasoning, enabling them to be able to engage in critical thinking, which was well epitomized by this student's formulation of "a lie paradox". In this novel classroom, students were permitted to contribute to the discourse the moment a new idea emerged, with a highly positive evaluation of the comment given by the teacher, forming a pattern of I R F distinct from the standard structure of I (R).

Furthermore, the students were also found to take the initiative in launching an opening move. During the discussion, one of the students proposed a solution to the ways of enjoying fiction, which was characterized by a long statement with abstract diction resulted from his critical thinking. Confronted with this logical and reasonable viewpoint, the teacher not only accepted the information provided by the student, but also evaluated it as "a very neat solution", and made comments on how to apply it to enjoying fiction as well. Therefore, in the free teaching exchange of student inform, the structure of initiation was directly followed by the feedback without the occurrence of response, based on which the structure of this teaching exchange is I F.

B. Teacher-student Interaction in the Poetry Classroom

TABLE 4

TEACHER-STUDENT INTERACTION IN THE POETRY CLASSROOM

\begin{tabular}{|c|c|c|c|}
\hline $\begin{array}{l}\text { Teaching } \\
\text { Exchange }\end{array}$ & $\begin{array}{l}\text { Opening (I) } \\
\text { Act, Move Structure }\end{array}$ & $\begin{array}{l}\text { Answering } \\
\text { (R) Act, MS }\end{array}$ & Fellow-up (F) Act, Move Structure \\
\hline Teacher Elicit & $\begin{array}{l}\text { Ok (marker, signal) } \\
\text { Let's go through this and see how we } \\
\text { are doing? So Dulce et Decorum Est by } \\
\text { Wilfred Owen. Line } 5 \text { (starter, } \\
\text { pre-head) where is this? Page } 11 \\
\text { (aides) "Men marched asleep. Many } \\
\text { had lost their boots". So "their" refers } \\
\text { to? (elicitation, head) Let's ask Jamie. } \\
\text { (nomination, select) }\end{array}$ & $\begin{array}{l}\text { Soldiers } \\
\text { (reply, head) }\end{array}$ & $\begin{array}{l}\text { Soldiers, ok } \\
\text { (evaluate, head) }\end{array}$ \\
\hline Teacher Elicit & $\begin{array}{l}\text { What particular soldiers are we talking } \\
\text { about? What the soldiers are doing right } \\
\text { now? } \\
\text { (elicitation, head) }\end{array}$ & $\begin{array}{l}\text { Marching asleep. } \\
\text { (reply, head) }\end{array}$ & $\begin{array}{l}\text { Ok, the soldiers are marching asleep. Yes } \\
\text { (evaluate, head) } \\
\text { The more specific you can be with your } \\
\text { description, the better. So the soldiers who are } \\
\text { marching asleep is better than the soldiers. } \\
\text { (comment, post-head) }\end{array}$ \\
\hline Teacher Elicit & $\begin{array}{l}\text { No. ten, with the light out, I was? } \\
\text { (elicitation, head) } \\
\text { Let's ask Lily, Lily } \\
\text { (nomination, select) }\end{array}$ & $\begin{array}{l}\text { Ardent } \\
\text { (reply, head) }\end{array}$ & $\begin{array}{l}\text { No, no, no. (evaluate, head) Ardent is an, um, } \\
\text { adjective. } \\
\text { (comment, post-head) }\end{array}$ \\
\hline $\begin{array}{l}\text { Bound } \\
\text { Exchange }\end{array}$ & $\begin{array}{l}\text { We need a verb form, don't we? (clue, } \\
\text { post-head) }\end{array}$ & $\begin{array}{l}\text { Enmeshed } \\
\text { (reply, head) }\end{array}$ & $\begin{array}{l}\text { No. (evaluate, head) } \\
\text { Fumbling ok? Fumbling means you try to find, } \\
\text { but you can't find, fumbling for the light switch. } \\
\text { (comment, post-head) }\end{array}$ \\
\hline Teacher Elicit & $\begin{array}{l}\text { No. eleven } \\
\text { (elicitation, head) } \\
\text { Windy (nomination, select) }\end{array}$ & $\begin{array}{l}\text { Smothered } \\
\text { (reply, head) }\end{array}$ & $\begin{array}{l}\text { Smothered, yes (evaluate, head) } \\
\text { a mother who kills her child by smothering with } \\
\text { a pillow. } \\
\text { (comment, post head) }\end{array}$ \\
\hline
\end{tabular}

In the poetry class, students were required to do a poetry preparation test designed by the teacher to check whether the students have studied the designated poems before class (See Table 4). The test was divided into two parts, with one part assessing students' capability of identifying the reference words in the poems, and the other evaluating the usage of the new vocabulary that has been come across when reading the poems. The spoken discourse in Table 4 was extracted from the part of the lesson when the teacher was about to check the answer with the students after the test was completed. The questions posed were designed and prepared in advance before the class, to which the key answers were 
known by the teacher with a view to assessing student's capability of their off-campus independent study.

The first two teaching exchanges took place when reference words were assessed, while the vocabulary was examined in the following three exchanges. In the first teaching exchange, the act of marker was perceived as a signal of the discourse boundary, followed by a short introduction indicating what would be conducted in the next phase. Attention was then attracted by the occurrence of the act of the aides, with the acts of elicitation and nomination ensuing to constitute the initiating move, based on which a fixed definite answer was provided by the student, which was affirmed in the follow-up move by the teacher's repetition of the reply. It was surprising to find that same interactive pattern was enacted in the second teaching exchange as well. Thus, it can be suggested that the structure of the teaching exchange was strictly in conformity with the combination of initiation, response and feedback (I R F), with certain fixed acts involved in each move characterized by the act of nomination following that of elicitation realizing the opening move, and by the act of reply, which was usually very brief, being the only act engaged in the answering move, as well as by the act of evaluate granted in the way of repeating what was stated by the student.

In the third teaching exchange, the usage of new vocabulary was examined, requiring students to fill in the blank with the most appropriate word to have the meaning completed in the sentence. The teaching exchange structure of I R F was clearly shown in Table 4 resting on the combination of both elicitation and nomination to motivate the students to contribute to the discourse, followed by a brief reply and the act of evaluate, which can be measured by a yes or no response. Since a wrong answer was generated, the bound exchange of re-initiation with the act of clue given by the teacher was designed to elicit an accurate response. However, another inaccurate answer emerged, explicitly reflected by the negative evaluate "no", in responding to which the teacher preferred to disclose the key answer serving as comment in the move of follow-up rather than initiating another bound exchange.

From this part, it can be seen that the reply to the question was, to some extent, fixed and brief, which can be evaluated as right or wrong, or even as yes or no in the follow-up move. When an inaccurate answer was elicited, the bound exchange of re-initiating was employed with the occurrence of initiating move realized by the act of clue, the structure of which tends to be I R F Ib R F. By contrast, if an accurate answer was given, the structure involved can often be perceived as I R F, with the response preceded by both elicitation and nomination and followed by the evaluate of right or wrong in conjunction with the act of comment.

TABLE 5

TEACHER-STUDENT INTERACTION IN THE POETRY CLASSROOM

\begin{tabular}{|c|c|c|c|}
\hline $\begin{array}{l}\text { Teaching } \\
\text { Exchange }\end{array}$ & $\begin{array}{l}\text { Opening (I) } \\
\text { Act, Move Structure }\end{array}$ & $\begin{array}{l}\text { Answering } \\
\text { (R) Act, MS }\end{array}$ & $\begin{array}{l}\text { Follow-up (F) } \\
\text { Act, Move Structure }\end{array}$ \\
\hline Teacher Elicit & $\begin{array}{l}\text { How about John Masefield's Cargoes? Is } \\
\text { the persona inside the poem or outside the } \\
\text { poem? (elicitation, head) } \\
\text { Jamie (nomination, select) }\end{array}$ & $\begin{array}{l}\text { Outside } \\
\text { (reply, head) }\end{array}$ & $\begin{array}{l}\text { Outside the poem. (evaluate, head) } \\
\text { There is no I or me in that poem, you don't } \\
\text { actually see the persona inside a poem and } \\
\text { again the persona is observing three different } \\
\text { images, three different historical periods but } \\
\text { outside the poem. } \\
\text { (comment, post-head) }\end{array}$ \\
\hline Teacher Elicit & $\begin{array}{l}\text { How about Dulce et Decorum Est? Is the } \\
\text { persona inside or outside the poem? } \\
\text { (elicitation, head) }\end{array}$ & $\begin{array}{l}\text { Inside } \\
\text { (reply, head) }\end{array}$ & $\begin{array}{l}\text { Inside the poem. Yes. } \\
\text { (evaluate, head) } \\
\text { Persona is there, and it talks about my dream. } \\
\text { (comment, post-head) }\end{array}$ \\
\hline Teacher Elicit & $\begin{array}{l}\text { Ok (marker, signal) } \\
\text { Claire, where is Claire? Claire (nomination, } \\
\text { select) can you say, can you describe the } \\
\text { persona? What do you think Wilfred will } \\
\text { be? (elicitation, head) }\end{array}$ & $\begin{array}{l}\text { He could be one of } \\
\text { the survivors in } \\
\text { the war. } \\
\text { (reply, head) }\end{array}$ & $\begin{array}{l}\text { Ok, he could be one of the survivors. } \\
\text { (evaluate, head). } \\
\text { He must be the survivor he wrote the poem. } \\
\text { (comment, post-head) }\end{array}$ \\
\hline Teacher Elicit & $\begin{array}{l}\text { Ok (marker, signal) } \\
\text { So the persona is someone who has } \\
\text { survived. (starter, pre-head) } \\
\text { What's specifically what has he survived? } \\
\text { He has survived what? (elicitation, head) }\end{array}$ & $\begin{array}{l}\text { Some, I guess } \\
\text { there are some } \\
\text { poisons that on top } \\
\text { of the air, and gas. } \\
\text { (reply, head) }\end{array}$ & $\begin{array}{l}\text { All right, he survived a gas attack. He } \\
\text { survived an attack by poison and gas, all } \\
\text { right? So the persona is someone who } \\
\text { survived an attack by poison and gas. } \\
\text { (evaluate, head) }\end{array}$ \\
\hline
\end{tabular}

Apart from the assessment of the reference words and vocabulary, here comes the introduction to the technical terms and practices of poetry analysis in the poem classroom (See Table 5). Poetic technical terms were taught with the help of an introductory handout listing both their names and their explanations. In the course of the pedagogic practice, the content in the introductory handouts was introduced first, which was then applied to the poems the students were learning. In this chosen episode, the term "persona" was introduced to better help students understand the poems.

Having finished introducing the theoretical concept of the term, the teacher initiated a discussion among the students to identify whether the persona was situated inside or outside the poems that they were reading. Closed questions posed by the teacher in the first two teaching exchanges for responses elicitation provided two choices for the students to answer, among which one of them was chosen by the student as a reply without any additional information added. Accordingly, positive feedback was granted by the teacher repeating the reply once again serving as the act of evaluate, facilitated by commenting on the reason why the reply was viewed as being accurate. Hence, it was evident that the teaching structure of I R F still exerted a strong influence on the teacher-student interaction in this poetry classroom. 
In the last two teaching exchanges, the most conspicuous feature was retrieved to be the application of the act of the marker, which was used at the beginning of a new teaching exchange, followed by the act of nomination and elicitation in the initiating move to signal an alteration of the discussion topic. Without being distracted from what was being discussed, the students' attention can be kept concentrated on what was being taught. Having identified the persona, the students were required to describe the persona by means of intensive reading and personal understanding. Following the act of elicitation in the opening move, within the routine, a verbal reply was given by the students with the act of evaluate being provided by the teacher by means of either repeating the reply or paraphrasing and summarizing what the student has responded, which realizes the follow-up move. Thus, the basic structure of teaching exchange of I R F has been conformed as well. Judging from what is displayed in Table 5, it was indicative that the teacher elicit has achieved a dominant position in the teaching exchange in this poetry classroom in the Hong Kong tertiary setting.

Given the above dissection, three distinctive features can be elaborated on here. In the first place, teacher-student interaction in this poetry classroom was highly affected by the basic structure of I R F, with questions containing choices having been posed, one of which can be chosen by the students perceived as the reply, followed by teacher's positive feedback by means of either repeating the answer or paraphrasing and summarizing the reply. In the second place, the act of marker was commonly employed by the teacher to signal the discourse boundary to keep the students concentrated on the lesson. Finally, the free teaching exchange of teacher elicit was placed in a dominant position in this poetry classroom in the Hong Kong tertiary setting.

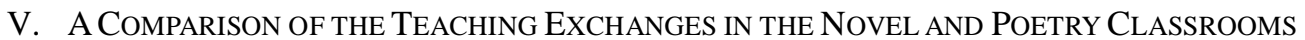

\section{A. Teacher Elicit versus Student Inform}

Teacher elicit and student inform belong to the sub-categories of the free teaching exchange with one characterized by the consistency of the typical structure of I R F beginning with the teacher's elicitation, and with the other commencing with the student's informative and ending with the feedback, without the occurrence of the answering move characterized by the structure of I F. In the novel classroom, the free teaching exchange of student inform has been presented in the last exchange shown in Table 4, in which the student takes the initiative in launching an interaction with the teacher. Having made a statement pertaining to the relevant topic serving as the act of informative, the student has won praise from the teacher with the inclusion of not only the head of evaluate, but also the pre-head of accept as well as the post-head of comment in the move of follow-up.

\section{B. Teacher Inform I $(R)$ versus Teacher Inform I R F}

Succeeding the teacher's instruction functioning as the act of informative in the opening move, response was provided by the student with only the act of comment being engaged in in the answering move, replacing the head of acknowledge, followed by the occurrence of the act of evaluate or accept in the follow-up move. The most contrasting difference between the standard pattern and the variation generated in the novel classrooms lies in the occurrence of feedback in the follow-up move. Based on the teacher's instruction, students in the novel classroom tended to make comment on what had been taught with a view to not only showing their understanding, but also to displaying their critical thinking by expressing their own viewpoint. Once the standpoint has been presented by the student, it is the teacher's responsibility to convey feedback, keeping the students informed of authority's opinion towards what they have contributed, from which they can benefit.

By contrast, this variation did not occur in the poetry classroom in the course of teacher's instruction, during which the students, situated in a relatively passive position in the classroom with the teacher-student interaction being launched primarily by the free teaching exchange of teacher elicit, tended to keep silent without contributing any verbal responses to the classroom discourse. Thus, the standard structure of teacher inform I (R) was conformed to only in the poetry classroom, with the variation coming into use in the novel classroom.

\section{A Comparison of the Acts Used In the Novel AND Poetry Classrooms}

\section{A. Open Elicitation versus Closed Elicitation}

As stated by Goody (1978), open questions can be referred to as "incomplete propositions, for which the answer provides the missing clause", while closed questions are "complete propositions which are answered simply yes or no" (p. 22). Accordingly, the open elicitation can be referred to as the questions which are initiated by the teacher requiring diverse answers with a long statement, which cannot be measured simply by right or wrong, and for the most part can be accepted as long as it is relevant and reasonable, while the closed elicitation can be considered as the questions which are posed needing to be worked out by particularly fixed and definite answers, which can be assessed by a right or wrong response.

In the novel classroom, the acts of elicitation applied were open and not constrained to produce a fixed answer, and accordingly the responses elicited from the students showed great diversity and sometimes took the form of long statements. Moreover, one distinctive feature could be noticed in the novel classroom different from another two classrooms in that the students were inclined to express their standpoint with a specified and detailed comment ensuing in responding to the yes-or-no questions. In the poetry classroom, the questions, being thought of as closed, related to 
the understanding of literary technical terms and the familiarity with vocabulary, and the responses elicited from the students were not only fixed, but also brief. It can also be seen from the spoken discourse that the questions in the poetry classroom tended to contain choices with one chosen by the students as a reply. In most cases, the key answers to the questions, which had been prepared in advance before the class, were known by the teacher, and were used to examine the learning outcome of the students.

\section{B. Diverse Reply versus Fixed Reply}

The act of the reply functioning as the head in the answering move was attached great importance to by all three teachers. Both open and closed elicitations from the teachers gave rise to the dichotomy between diverse reply and fixed reply. A diverse reply was usually characterized by the expression of a personal viewpoint on certain controversial issues with a long and detailed statement which could be understood from different perspectives, while the fixed reply corresponding to the closed questions was characterized by the formation of a rigid key answer with a short and brief utterance, with other deviant answers being repelled by the authority.

Another distinction between them lay in whether they could be measured by right or wrong. A diverse reply, to some extent, could not be evaluated by the dichotomy and could be approved by the teacher as long as the answer was relevant, reasonable, and logical, while in the case of a fixed reply, it could only be assessed by right or wrong in accordance with the key answer established. In the novel classroom, the act of reply contributed by the student was normally diverse with a high proportion of the open elicitations launched in the opening move. By comparison, the replies were relatively fixed and brief in the poetry classroom in accordance with the closed elicitations posed.

\section{Positive Evaluate versus Negative Evaluate}

Feedback, the last phase of the structure of the free exchange I R F, was of great importance in the classroom exchange, on which interactive teaching and learning largely hinge, realized by the acts of accept, evaluate and comment. The act of evaluate as the head realizing the follow-up move plays a crucial role in the improvement and enhancement of the learning outcome. Having received responses proposed by the students, the teacher is responsible for evaluating the reply, which is compulsory in other words. Through evaluation, on the one hand, the consciousness of the learning inadequacy has been raised by keeping the students informed of what mistakes have been made in their responses. On the other hand, the students tend to be stimulated and motivated in study by the positive evaluation granted by the teacher. The expression of positive and negative evaluation displayed differences in the spoken discourse of teacher-student interaction in the novel and poetry classrooms.

In the novel classroom, the positive evaluation was expressed in a direct and explicit manner, while the negative evaluation was presented in a more objective and roundabout way. By comparison, in the poetry classroom, the act of positive evaluate was, for the most part, characterized by the repetition of the reply made by the students with comment ensuing at the end. With respect to the expression of the act of negative evaluate, it has been voiced by a direct and rather straightforward negation of "no" in contrast to a roundabout verbal expression in the novel classroom. However, it seems that the individual teaching style counts in engendering this distinction as well.

\section{PedAGOGICAL IMPLiCATIONS}

The characteristics of the teacher-student interaction in the novel and poetry classrooms have been identified, based on which the distinction among these three literary genres has been explicated. In the novel classroom, critical thinking was cultivated, with the foreign language of English being perceived as a medium or a tool for sending the message regarding the understanding of the novel. It is the literary message that was focused on in the novel classroom, in which students were required to express their own viewpoints from a certain perspective and the discourse was characterized by teacher's open elicitation and students' diverse reply with long statements.

In the poetry classroom, the enlargement of the vocabulary, which was considered as an essential prerequisite for the comprehension of a poem, was attached great importance, with the instruction being characterized by a closed elicitation followed by a fixed reply that could be evaluated by the right or wrong dichotomy. More often than not, vocabulary drills were held in the poetry classroom prior to the systematic introduction to the poetic technical terms and the poem itself. With the absence of a good command of the necessary English vocabulary, the understanding of a poem tends to be insufficient. With the explanation of the unfamiliar vocabulary being a prerequisite for poetry teaching, the introduction to poetic technical terms are integrated with certain selected poems by means of building recognizable relations between them. In that case, poems were counted as the supplementary samples assisting the students in understanding the poetic technical terms.

\section{POTENTIAL APPLICATIONS OF THE RESEARCH}

An insight into the teacher-student interaction in the literature classroom has been provided by this study, with the interactive structure as well as the interactive distinction in the novel and poetry classrooms being revealed, which could enable literature teachers to maximize the potential of literature classrooms in the Hong Kong tertiary setting.

Specifically speaking, in the first place, literature teaching with respect to different literary genres tends to enable students to acquire knowledge of more than one area, with the skills of text appreciation, critical thinking, the 
enlargement of the vocabulary, and the command of technical terms being further enhanced.

In the second place, it could be useful for literature teachers to bear in mind that the structure of the teacher-student interaction can vary considerably from one sub-genre to another, which will contribute to distinct learning outcomes yielded by different literary genres. Thus, special attention to the different interactive focus constructing distinct interactive structure in literature teaching should be paid, with a view to realizing the optimum effect of literature learning.

Finally, different internal linguistic constructions of the classroom interaction between teachers and students derived from the instruction of the native speaking teachers in the sub-genres of the literature classroom have been explored. It can, on the one hand, stimulate and reinforce the non-native teachers' consciousness of the benefit that different literary genres bring for students' all-round development with respect to language and literature. On the other hand, it can provide a solid theoretical teaching reference for the non-native literature teachers.

\section{REFERENCES}

[1] Allwright, D., \& Bailey, K. M. (1991). Focus on the language classroom: An introduction to classroom research for language teachers. Cambridge; New York: Cambridge University Press.

[2] Bailey, K. M., \& Nunan D. (eds.) (1996). Voices from the language classroom: Qualitative research in second language education. Cambridge; New York: Cambridge University Press.

[3] Basturkmen, H. (2000). The organization of discussion in university settings. Text, 20(3), 249-269.

[4] Chaudron, C. (1983). Foreigner talk in the classroom-An aid to learning? In H. W. Seliger and M. H. Long (eds.) Classroom oriented research in second language acquisition. Rowley, Massachusetts: Newbury House Publishers, 127-145.

[5] Chaudron, C. (1988). Second language classrooms: Research on teaching and learning. Cambridge; New York: Cambridge University Press.

[6] Collie, J., \& Slater, S. (1987). Literature in the language classroom: A resource book of ideas and activities. Cambridge; New York: Cambridge University Press.

[7] Coulthard, M. (1975). Discourse analysis in English: A short review of the literature. Language Teaching and Linguistics Abstracts, 8, 73-89.

[8] Cullen, R. (2002). Supportive teacher talk: The importance of the F-move. ELT Journal, 56 (2), 117-127.

[9] Dalton-Puffer, C. (2007). Discourse in content and language integrated learning (CLIL) classrooms. Amsterdam/Philadelphia: John Benjamins Publishing Company.

[10] Goody, E. N. (1978). Towards a theory of questions. In E. N. Goody (eds.) Questions and politeness: Strategies in social interaction. Cambridge: Cambridge University Press.

[11] Hellermann, J. (2003). The interactive work of prosody in the IRF exchange: Teacher repetition in feedback moves. Language in Society, 32(1), 79-104.

[12] Lee, Y. A. (2007). Third turn position in teacher talk: Contingency and the work of teaching. Journal of Pragmatics, 39, 1204-1230.

[13] Nassaji, H., \& Wells, G. (2000). What's the use of 'triadic dialogue'?: An investigation of teacher-student interaction. Applied Linguistics, 21(3), 376-406.

[14] Parkinson, B., \& Thomas, H. R. (2000). Teaching literature in a second language. Edinburgh: Edinburgh University Press.

[15] Schinke-Llano, L. A. (1983). Foreigner talk in content classrooms. In H. W. Seliger and M. H. Long (eds.) Classroom oriented research in second language acquisition. Rowley, Massachusetts: Newbury House Publishers, 146-165.

[16] Sinclair, J. (1987). Classroom discourse: Progress and Prospects. RELC Journal, 18(2), 1-14.

[17] Sinclair, J. McH. \& Brazil, D. (1982). Teacher talk. Oxford: Oxford University Press.

[18] Sinclair, J. McH., \& Coulthard, R. M. (1975). Towards an analysis of discourse: The English used by teachers and students. London: Oxford University Press.

[19] Van Dijk, T. A. (1985). Preface to the Four Volumes. In T. A. Van Dijk (eds) Handbook of discourse analysis: Disciplines of discourse (Volume 1). London: Academic Press, xi-xii.

[20] Van Dijk, T. A. (1985). Introduction: Discourse analysis as a new cross-discipline. In T. A. Van Dijk (eds) Handbook of discourse analysis: Disciplines of discourse (Volume 1). London: Academic Press, 1-10.

[21] Walsh, S. (2002). Construction or obstruction: Teacher talk and learner involvement in the EFL classroom. Language Teaching Research, 6(1), 3-23.

[22] Wu, K. Y. (1993). Classroom interaction and teacher questions revisited. RELC Journal, 24(2), 49-68.

Dan Shi was born in Ningbo, China in 1986. She received her MA in English Language Studies from The Hong Kong Polytechnic University, Hong Kong in 2009.

She is currently a PhD Candidate majoring in English Language Education in the Faculty of Education at The University of Hong Kong. Her main research areas are functional linguistics, multimodality and classroom discourse analysis. 